\title{
Persepsi iklan Lifebuoy Pencegah Covid-19 di Kelurahan Tempel Rejo Rejang Lebong
}

\author{
Edo Wiranto ${ }^{1}$, Robby Aditya Putra ${ }^{2}$, Hariya Toni ${ }^{3}$ \\ Institut Agama Islam Negeri (IAIN) Curup \\ edowiranto55@gmail.com/hariyatoni@iaincurup.ac.id
}

\begin{abstract}
This study aims to determine public perceptions of advertising to prevent the spread of the Covid-19 virus. To describe this perception, the researcher focused on several sub-categories, namely applications through the sense of sight and sense of hearing so as to produce people's perceptions of messages in advertisements. The research method in this study used a qualitative approach, namely descriptive analysis. The subjects in this study were 3 people. Data collection techniques through indepth interviews, observation, documentation and internet searching. The results of the study illustrate that, the application of perception through the sense of sight is very positive, where people consider the visuals displayed in this advertisement to be very attractive so that people do not get bored seeing it. The application of perception through the sense of hearing is also very good, because the audio presentation displayed in this advertisement uses language that is easy to understand and is accompanied by music. The public's perception of this message as a whole is positive. The conclusion of this research is the public's perception is that this advertisement attracts people's attention and changes people's behavior to follow the contents of the message in the advertisement, namely steps to protect themselves from the spread of the Covid-19 virus.
\end{abstract}

Keyword: Perception, Advertisement, Covid-19

Abstrak. Penelitian ini bermaksud untuk mengetahui Persepsi Masyarakat mengenai Iklan pencegahan penyebaran virus Covid-19. Untuk mendeskripsikan mengenai persepsi tersebut, peneliti memfokuskan kedalam beberapa sub yaitu penerapan melalui indera penglihatan dan indera pendengaran sehingga menghasilkan Persepsi Masyarakat mengenai Pesan dalam Iklan. Metode Penelitian pada penelitian ini menggunakan pendekatan kualitatif yang bersifat deskriptif analisis. Subjek dalam penelitian ini berjumlah 3 orang. Teknik pengumpulan data melalui wawancara mendalam, observasi, dokumentasi serta internet searching. Hasil Penelitian menggambarkan bahwa, penerapan persepsi melalui indera penglihatan sangat positif, dimana masyarakat menganggap visual yang ditampilkan iklan ini sangat menarik sehingga masyarakat tidak bosan melihatnya. Penerapan persepsi melalui indera pendengaran juga sangat bagus, karena sajian audio yang ditampilkan iklan ini menggunakan bahasa yang mudah dipahami dan disertai dengan musik. Persepsi masyarakat mengenai pesan ini secara keseluruhan adalah positif. Simpulan dari penelitian ini adalah persepsi masyarakat adalah bahwa iklan ini menarik perhatian masyarakat dan mengubah perilaku masyarakat untuk mengikuti isi pesan dalam iklan yaitu langkah-langkah untuk melindungi diri dari penyebaran virus Covid-19.

Kata kunci. Persepsi, Iklan, Covid-19. 


\section{PENDAHULUAN}

Awal mula pandemi Covid-19 di Indonesia bermula di bulan FebruariMaret 2020 yang pada awalnya warga negara asing positif Covid-19 kontak langsung dengan warga negara Indonesia seorang wanita yang bekerja sebagai guru dansa. Penyakit ini disebabkan oleh coronavirus jenis baru yang diberi nama $S A R S$-CoV-2. Pandemi ini pertama kali muncul di Wuhan China pada bulan Desember 2019 dan ditetapkan sebagai pandemi oleh Organisasi Kesehatan Dunia (WHO) pada 11 Maret 2020. (Nuzuli, 2020; Adityo, dkk 2020)

Data statika pasien corona di Indonesia pada bulan september sebanyak 112.212 kasus selama satu bulan. Pada tanggal 10 september kasus baru bertambah 3.861 kasus, 16 september sebanyak 3.963 kasus baru, 19 september sebanyak 4.168 kasus baru, dan 21 september sebanyak 4.176 kasus baru. Selain itu di penghujung september, tercatat penambahan kasus harian memecahkan rekor selama tiga hari berturut-turut, mulai dari 23 sampai dengan 25 september.Sejak resmi dikonfirmasi oleh pemerintah pada awal Maret, pasien virus corona di Indonesia hingga september berjumlah 287.008 kasus. Dari jumlah tersebut, 214.947 dinyatakan sembuh, dan 10.740 orang meninggal dunia. (Shafa, 2021)

Dari data diatas menunjukkan bahwa jumlah pasien covid-19 mengalami kenaikan setiap harinya. Situasi ini membuat pemerintah Indonesia mulai bergerak dalam upaya penyebaran informasi dan himbauan terkait Covid-19, Setelah World Health Organization (WHO) menyatakan bahwa situasi dinyatakan pandemi, yang artinya virus ini sudah meluas dan tersebar di berbagai belahan negara atau mewabah dalam skala yang besar dan luas. Menteri kesehatan Republik Indonesia yaitu Achmad Yurianto ditunjuk sebagai juru bicara terkait semua tentang Covid-19 (Nuzuli, 2020b).

Seiring dengan perkembangan teknologi dan informasi, saat ini media massa mengambil peranan penting dalam kehidupan masyarakat. (Ronald, 2006) Media massa merupakan alat penyebar informasi yang sangat efektif dan digunakan untuk menyampaikan pesan dari pihak komunikator kepada pihak komunikan. Lewat media massa, pesan bisa sampai pada khalayak luas dalam waktu yang singkat. Hal ini lah yang dimanfaatkan pemerintah Indonesia dalam memberikan pengetahuan terkait langkah untuk mencegah penyebaran covid19

Media komunikasi modern yang banyak digunakan adalah media televisi, berbagai bentuk program dan siaran yang ditayangkan. Salah satu teori 
komunikas tv yang menjelaskan bagaimana individu masyarakat dalam menggunakan media komunikasi, adalah teori mass media uses and gratification dari Katz, Gurevitch dan Hass. Teori yang menurut Tankard tergolong dalam teori efek media berkategori moderat ini (Tankard, 1986).

Teori tersebut dilandasi oleh kebutuhan perorangan yang dipengaruhi oleh lingkungan sosialnya. Istilah "kebutuhan" yang merupakan padanan kata "need" itu sendiri, dalam psikologi digunakan juga sebagai padanan dari kata-kata: "motives", "wants", "desires", dan lain lain. Televisi juga merupakan salah satu media komunikasi yang dimiliki oleh pihak atau perusahaan tertentu untuk menyampaikan pesan dan memberi kesadaran serta pendidikan kepada khalayak. perusahaan dapat memperkenalkan dan menginformasikan produk serta manfaat yang diterima oleh khalayak. Salah satu cara yang dilakukan adalah memberi kesadaran dan pendidikan kepada khalayak melalui pesan iklan layanan masyarakat. Perusahaan yang ikut berpartisipasi dalam membuat iklan layanan masyarakat adalah PT Unilever.

PT Unilever merupakan perusahaan yang bergerak di bidang sandang dan pangan. PT Unilever saat ini berkontribusi dalam salah satu iklan layanan masyarakat yang terkait dengan Covid-19. Virus yang diduga muncul pertama kali di Wuhan China tersebut telah menyebar ke berbagai negara dunia termasuk Indonesia. Cara Covid-19 ini menyebar melalui percikan dari hidung atau mulut yang keluar saat orang yang terinfeksi batuk, bersin atau berbicara. Dengan mempraktikkan kebersihan tangan serta menjaga protokol kesehatan lainnya sangatlah penting dan merupakan cara terbaik untuk melindungi dari penyebaran virus Covid-19.

Iklan layanan masyarakat terkait dengan virus Covid-19 adalah iklan Lifebuoy 5 langkah lawan penyebaran virus Corona (Covid-19). Iklan yang dibintangi oleh Titi Kamal, Christian Sugiono serta dr. Kuntjoro Adi yang berdurasi 30 detik ini memberi informasi untuk melakukan cuci tangan dengan menggunakan sabun kemudian aplikasikan Hand Sanitizer berbasis alkohol saat berada di luar rumah, waspada selalu terhadap batuk dan bersin menggunakan 
masker atau tisu, anjuran untuk yang sakit segera hubungi dokter, no kumpul bareng dan dianjurkan dirumah aja.

Tujuan dari iklan Lifebuoy ini sangat jelas yaitu untuk mengingatkan masyarakat agar menjaga kebersihan tangan dan menggunakan sabun apapun yang dapat mengurangi pencegahan penularan virus Covid-19. Hal sederhana ini sangat lah penting guna melindungi diri, keluarga dan lingkungan.

Maka dari itu penulis tertarik untuk meneliti bagaimana persepsi

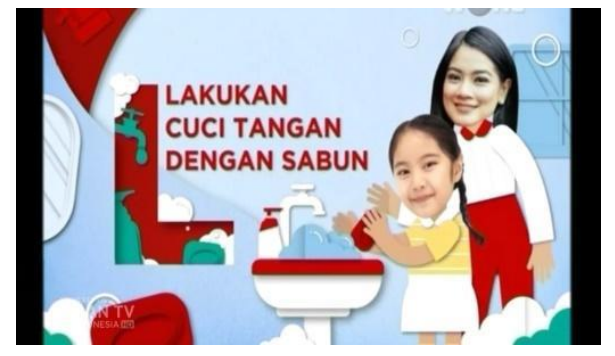
masyarakat Tempel Rejo tentang iklan Lifebuoy Layanan Masyarakat yang menyangkut 5 langkah lawan penyebaran virus corona (Covid-19). Melihat kondisi saat ini di wilayah Tempel Rejo belum ada pasien yang positif Covid19 dan masyarakat tetap waspada terhadap virus ini dan telah melaksanakan protokol kesehatan salah satunya menggunakan masker dan mencuci tangan dengan sabun.

Adapun fokus penelitian ini adalah bagaimana penerapan melalui penglihatan dan pendengaran sehingga menimbulkan persepsi bagi masyarakat Kelurahan Tempel Rejo tentang iklan Lifebuoy 5 langkah lawan penyebaran virus corona(covid-19). Tujuan dalam penelitian ini adalah untuk mengetahui bagaimana penerapan penglihatan dan pendengaran masyarakat di Tempel Rejo dan bagaimana persepsi masyarakat terhadap iklan tersebut.

Manfaat penelitian ini dari segi teoritis diharapkan memberikan kontribusi khazanah kepustakaan atau ilmu pengetahuan kepada mahasiswa/i terutama Jurusan Dakwah khususnya Program studi Komunikasi dan Penyiaran Islam tentang persepsi masyarakat kel. Tempel Rejo terhadap iklan layanan masyarakat Covid-19.Adapun manfaat praktis bagi penulis ialah untuk meningkatkan pengetahuan, pengalaman praktis, dan juga merupakan kesempatan yang berharga bagi penulis dalam menerapkan pengetahuan yang selama ini diperoleh dan selama menempuh perkuliahan.Dan Bagi PT. Unilever merupakan bahan evaluasi yang dapat dipertimbangkan untuk meningkatkan kinerja perusahaan.

Metode dalam penelitian ini menggunakan penelitian kualitatif yang bersifat deskriptif analisis, penelitian kualitatif adalah penelitian yang bersifat interpretif (menggunakan penafsiran) yang melibatkan banyak metode dalam menelaah masalah penelitiannya . Peneliti kualitatif lazim menelaah hal-hal yang berada dalam lingkungan alamiahnya, berusaha memahami, atau menafsirkan fenomena berdasarkan makna-makna yang orang berikan kepada 
hal-hal tersebut. (Dedy Mulyana dan Solatun, 2007: 5) Tempat dan waktu dalam penelitian ini dilaksanakan di kelurahan Tempel Rejo kabupaten Rejang Lebong. Adapun penelitian ini dilakukan pada bulan september 2020.

Subjek dalam penelitian ini adalah pihak-pihak yang dapat memberikan informasi yang diperlukan oleh peneliti. Narasumber atau informan adalah orang yang bisa memberikan informasi-informasi utama yang dibutuhkan dalam penelitian. Dalam penelitian survei sosial, subjek penelitian ini adalah manusia. (Suharsimi Arikunto, 2006) Dalam penelitian ini subjek merupakan objek yang akan memberikan informasi-informasi terkait masalah yang akan diteliti. Subjek dari penelitian ini adalah masyarakat kelurahan Tempel Rejo.

Teknik pengumpulan data adalah langkah yang paling strategis dalam penelitian, karena tujuan dari penelitian adalah mendapatkan data. Tanpa mengetahui teknik pengumpulan data, maka peneliti tidak akan mendapatkan data yang memenuhi data yang ditetapkan. (Lexy J. Moleong, 2006) Pengumpulan data dapat dilakukan dalam berbagai setting, berbagai sumber, dan berbagai cara. Bila dilihat dari setting-nya, data dapat dikumpulkan pada setting alamiah (natural setting), pada laboratorium dengan metode eksperimen, di rumah dengan berbagai responden, pada suatu seminar, diskusi, di jalan dan lain-lain. Bila dilihat dari sumber datanya, maka pengumpulan data dapat menggunakan sumber primer dan sumber sekunder. Sumber primer adalah sumber yang langsung memberikan data kepada pengumpul data dan sumber sekunder merupakan sumber yang tidak langsung memberikan data kepada pengumpul data misalnya lewat orang lain atau dokumen. (Sugiyono, 2014)

Adapun teknik penelitian yang digunakan oleh peneliti adalah sebagai berikut :

Sanafiah Faisal mengklasifikasikan observasi menjadi observasi berpartisipasi (participant observation), observasi yang secara terang-terangan dan tersamar (over observation and covert observation), dan observasi yang tak berstruktur (unstructured observation). (Sukarman Syarnubi, $\{\mathrm{tt}\}:$ )

Oleh karena itu untuk mendapatkan data yang akurat peneliti menggunakan teknik observasi yang secara terang-terangan dan tersamar. Dalam hal ini, peneliti dalam melakukan pengumpulan data menyatakan terus terang kepada sumber data, bahwa peneliti sedang melakukan penelitian pada iklan layanan masyarakat yaitu iklan Lifebuoy. Jadi mereka yang diteliti mengetahui sejak awal sampai akhir tentang aktivitas peneliti. Tetapi dalam suatu saat peneliti juga tidak terus terang atau tersamar dalam observasi, hal ini 
untuk menghindari kalau suatu data yang dicari merupakan data yang masih di rahasiakan..

Wawancara digunakan sebagai teknik pengumpulan data, wawancara ialah merupakan pertemuan antara dua orang untuk bertukar informasi dan ide melalui Tanya Jawab, sehingga dapat dikonstruksikan makna dalam suatu topik tertentu. (Koenjradiningrat, 1997:) Melalui wawancara ini peneliti mengajukan beberapa pertanyaan secara lisan atau langsung bertatap muka kepada orang yang menjadi objek dari penelitian ini. Tentunya dalam kegiatan wawancara peneliti akan mematuhi protokol kesehatan yaitu menggunakan masker dan jaga jarak.

Peneliti melakukan wawancara untuk melengkapi data-data yang diperlakukan. Wawancara tersebut dilakukan oleh peneliti kepada masyarakat yang ada di Kelurahan Tempel Rejo.

Untuk melakukan analisis, setelah data terkumpul metode analisis data yang digunakan adalah analisis deskriptif kualitatif artinya menganalisa keadaan dan menginterpretasikan data dengan cara menggambarkan dan melukiskan keadaan subjek, objek dan data-data yang lain dalam penelitian pada saat sekarang berdasarkan fakta yang ada.( Handari Nawawi, 1990) Analisa data merupakan upaya mencari dan menata secara sistematis catatan hasil observasi, wawancara, dan lainnya untuk meningkatkan pemahaman peneliti tentang kasus yang diteliti dan menyajikannya sebagai temuan bagi orang lain. (Noeng Muhadjir, 1998)

\section{HASIL DAN PEMBAHASAN}

\section{Pengertian Persepsi}

Kata persepsi diambil dari kata perception (Inggris) yang artinya menerima atau mengambil. Persepsi merupakan salah satu aspek psikologis yang penting bagi manusia dalam merespon kehadiran berbagai aspek dan gejala di sekitarnya. Beberapa ahli telah memberikan definisi yang beragam tentang persepsi, walaupun pada prinsipnya mengandung makna yang sama. Menurut Kamus Besar Bahasa Indonesia, persepsi adalah tanggapan (penerimaan) langsung dari sesuatu. Proses seseorang mengetahui beberapa hal melalui panca inderanya. (Babbie E. 1992)

Sementara Pengertian persepsi menurut Slameto (2003) menyatakan persepsi adalah proses yang menyangkut masuknya pesan dan informasi di dalam otak manusia. Informasi dan pesan yang diterima tersebut muncul dalam 
bentuk stimulus yang merangsang otak untuk mengolah lebih lanjut yang kemudian mempengaruhi seseorang dalam berperilaku. (bttp:// digilib.unila.ac.id/8016/14/BAB\%20II.pdf)

Persepsi adalah pemaknaan atau arti terhadap informasi (energi/stimulus) yang masuk ke dalam kognisi manusia (Nuzuli, 2018). Persepsi adalah pengalaman tentang objek, peristiwa, atau hubunganhubungan yang diperoleh dengan menyimpulkan informasi dan menafsirkan pesan. Persepsi ialah memberikan makna pada stimuli inderawi (sensori stimuli). (W. Syam Nina, 2011)

\section{Iklan Pencegahan Covid-19}

Siaran iklan televisi pertama kali mengudara pada tahun 1941, tahun itu tahun pertama mengudaranya siaran televisi komersial. Perusahaan Bulova Watch Company yang menjadi perusahaan pertama kali iklannya ditayangkan di televisi dan membayar sekitar sembilan dolar. (Morissan, 2008) Iklan adalah berita atau pesan yang disampaikan untuk membujuk dan mendorong orang agar tertarik pada barang ataupun jasa yang ditawarkan, iklan biasa dipromosikan melalui media periklanan seperti,televisi, radio, koran, majalah, internet dll. Iklan mengandung pemberitahuan kepada masyarakat dan bersifat mempengaruhi pembaca agar melakukan apa yang dikehendaki. Iklan tidak terbatas pada produk, melainkan juga pada informasi, ajakan atau seruan untuk melakukan suatu hal. Seperti contohnya ajakan untuk melindungi diri ditengah pandemi covid-19.

Saat ini pemerintah berupaya melakukan berbagai cara untuk mencegah penyebaran virus covid-19 yang telah menyebar ke wilayah Indonesia. Dengan menyebar informasi ke berbagai media seperti himbauan mencuci tangan menggunakan media poster, spanduk, koran, dan iklan televisi. Salah satu protokol kesehatan yang dianjurkan Organisasi Kesehatan Dunia (WHO) untuk memerangi Covid-19 adalah mencuci tangan. Salah satu iklan layanan masyarakat yang telah ikut berpartisipasi dalam mencegah penyebaran virus covid-19 adalah iklan Lifebuoy "5 langkah lawan penyebaran virus covid19”. Hal ini juga sejalan dengan komitmen Lifebuoy yang sudah berjalan 86 tahun. Lifebuoy pun berkomitmen untuk memberikan solusi kebersihan yang terjangkau serta mendukung kebersihan tangan yang baik. Lifebuoy mengambil peran yang besar dalam memastikan masyarakat dapat menjaga kebersihan tangan dimanapun mereka berada melalui rangkaian produknya yang berkualitas. (https://www.klikdokter.com/info-sehat/read/3640071/cucitangan-cara-paling-ampuh-dan-mudah-perangi-covid-19) 
Dalam melindungi diri dari penyebaran virus corona atau Covid-19, kebersihan tangan merupakan salah satu kunci utama untuk menjaga kesehatan masyarakat di saat pandemi ini. Berbagai penelitian selama bertahun-tahun telah menunjukkan bahwa mencuci tangan dengan sabun dan air secara teratur, seperti yang direkomendasikan oleh Organisasi Kesehatan Dunia (WHO), sangat efektif dalam melawan kuman. Karena itu, berbagai inovasi terus dilakukan Lifebuoy agar dapat memberikan perlindungan menyeluruh demi menciptakan tangan Indonesia yang sehat.Baru-baru ini sebuah penelitian dilakukan Laboratorium Akreditasi Internasional, Microbac Laboratories, dengan Lifebuoy hand sanitizer berbasis alkohol. Lifebuoy adalah brand sabun pertama di dunia yang melaporkan bahwa hand sanitizernya yang berbasis alkohol efektif melawan virus Covid-19. Hand sanitizer berbasis alkohol bekerja dengan cara menghancurkan lapisan pelindung luar virus sehingga virus menjadi tidak aktif.

Sejalan dengan itu, Lifebuoy berkomitmen untuk memberikan solusi kebersihan yang terjangkau serta mendukung kebersihan tangan yang baik, dan memastikan masyarakat dapat menjaga kebersihan tangan dimanapun berada.Mengusung semangat mari berbagi peran Lifebuoy memastikan masyarakat Indonesia dapat mengakses produk Lifebuoy dengan mudah untuk membantu mereka secara optimal dalam hal personal hygiene.

Selama masa pandemi ini Lifebuoy melakukan percepatan produksi untuk memastikan bahwa tidak hanya konsumen menerima manfaat, namun juga menyalurkan produk-produk tersebut ke fasilitas umum seperti rumah sakit dan juga masyarakat yang membutuhkan, dan disalurkan baik secara independen maupun dalam kemitraan dengan berbagai lembaga resmi terpercaya di Indonesia. Tidak hanya memastikan ketersediaan produk, sejak awal tahun, Lifebuoy juga telah memproduksi dan menerbitkan bahan edukasi yang menekankan pentingnya menjaga kebersihan diri dalam bentuk Iklan Layanan Masyarakat. Hal ini dilakukan untuk senantiasa mengingatkan masyarakat agar menjaga kebersihan tangan dan menggunakan sabun apapun yang dapat mengurangi pencegahan penularan virus corona (covid-19)

Pada umumnya iklan layanan masyarakat bertujuan mendorong konsumen untuk merubah perilakunya. (Priliantini, A. 2017). Dengan harapan yaitu masuknya pesan dan informasi kedalam otak manusia. Dari konsep slameto informasi dan pesan yang diterima tersebut muncul dalam bentuk stimulus yang merangsang otak untuk mengolah lebih lanjut yang kemudian mempengaruhi seseorang dalam berperilaku. Aspek yang dianalisis yaitu 
tentang persepsi masyarakat Tempel Rejo terhadap iklan layanan masyarakat terkait Lifebuoy 5 langkah lawan penyebaran virus corona (covid-19) dimana iklan tersebut memberi himbauan dan edukasi terhadap masyarakat Indonesia. Perilaku masyarakat merupakan hal yang dipengaruhi oleh segala aspek berupa stimulus atau rangsangan yang diberikan sehingga timbul persepsi dan perilaku baru. Dari adanya iklan layanan masyarakat Lifebuoy terkait pencegahan penyebaran covid-19 maka timbullah persepsi dan perilaku baru sebab informasi juga merupakan salah satu kebutuhan masyarakat.

Berbagai cara yang telah dijalankan oleh media massa terutama televisi setidaknya mengurangi dampak penyebaran covid-19 terhadap masyarakat. Dalam iklan tersebut dijelaskan mengenai 5 cara mencegah penyebaran covid19 dengan mencuci tangan dengan menggunakan sabun batang atau sabun cair kemudian aplikasikan Handsanitizer, waspada batuk bersin dan harus menggunakan masker, anjuran untuk yang sakit untuk segera hubungi dokter, dan tidak berkumpul di tempat keramaian.

Hasil penelitian peneliti mendeskripsikan bagaimana teori penerapan persepsi masyarakat kelurahan Tempel Rejo terhadap iklan lifebuoy ini dan dikaitkan dengan hasil di lapangan sebagai berikut:

\section{Penerapan Melalui Penglihatan}

Untuk mempersepsi sesuatu individu harus mempunyai perhatian kepada objek yang bersangkutan. Apabila individu telah memperhatikan, selanjutnya individu menyadari sesuatu yang diperhatikan itu, atau dengan kata lain individu mempersepsi apa yang diterima dengan alat inderanya. Individu dapat menyadari apa yang dilihatnya, didengarnya, dirabanya dan sebagainya. Alat indera merupakan alat utama dalam individu mengadakan persepsi. Seseorang dapat melihat dengan matanya tetapi mata bukanlah satu-satunya bagian sehingga individu dapat mempersepsi apa yang dilihatnya, mata hanyalah merupakan salah satu alat atau bagian yang menerima stimulus, dan stimulus ini dilangsungkan oleh saraf sensoris ke otak, hingga akhirnya individu dapat menyadari apa yang dilihat. (Walgito Bimo, 2004)

Visi atau penglihatan merupakan indera manusia yang paling utama. Dengan melihat sesuatu objek maka dapat disimpulkan si penglihat objek tersebut akan menerapkan teori persepsi ini dari apa yang telah dilihatnya. Karena pada umumnya hal pertama yang membuat atau menimbulkan adanya persepsi ini dikarenakan dari penglihatan dari individu yang sedang mengamati satu objek tertentu. 
Dalam Iklan Lifebuoy 5 langkah lawan penyebaran virus corona (Covid19) memperlihatkan bintang iklan yang sedang memberikan informasi dengan visual yang di desain semenarik mungkin supaya hanya dengan melihat iklan tersebut langsung bisa dipahami oleh khalayak yang menyaksikan.

Hal inilah yang dirasakan oleh masyarakat Kelurahan Tempel Rejo setelah menonton iklan Lifebuoy 5 langkah lawan penyebaran virus corona (Covid-19), seperti yang diutarakan Bima Praja, salah satu masyarakat Kelurahan Tempel Rejo, Kabupaten Kepahiang:

"Setelah melihat iklan ini saya langsung tertarik dengan pesan yang disampaikan, bagi saya gambar yang ditampilkan sangat mudah dipahami dan tidak membuat saya bosan, karena langsung di praktekan dan disertai dengan tulisan keterangan yang unik dan juga ada animasi nya, sehingga hanya dengan melihat iklan tersebut saya langsung pabam dan mudah untuk dipraktekkan "(Bima Praja, wawancara, 2020)

Berdasarkan hasil wawancara mendalam, dari segi visual informan mengatakan bahwa iklan Lifebuoy 5 langkah lawan penyebaran virus corona (Covid-19) memberikan ilustrasi yang mudah dipahami, memang cara penyampaian pesan dalam iklan harus unik dan menarik khalayak sasaran agar ikut bertindak sesuai dengan pesan yang disampaikan. Di dalam menentukan isi pesan yang baik, perlu adanya daya tarik yang unik, itulah yang saat ini ditampilkan oleh iklan Lifebuoy ini sehingga benar-benar mempengaruhi masyarakat perilaku masyarakat.

Dalam membuat sebuah iklan memang harus dikemas dengan semenarik mungkin (Ambar, 2013), tujuannya adalah senantiasa mengingatkan masyarakat untuk menjaga kebersihan dan juga memberikan dampak yang positif bagi kehidupan masyarakat. Iklan Lifebuoy ini bisa dibilang cukup efektif dalam mempengaruhi persepsi masyarakat, dengan desain tampilan yang dibuat hanya dengan durasi 30 detik menjadikan masyarakat betah menyaksikan iklan tersebut hingga selesai. Hal itu lah yang membuat iklan Lifebuoy Bukan hanya menampilkan cara mencuci tangan saja tetapi juga lima tahapan langsung dalam satu iklan. Iklan Lifebuoy juga terus menjaga komitmen dimana dari masa ke masa ingin memberikan yang terbaik agar kesehatan masyarakat dapat terus terjaga.

\section{Penerapan Melalui Pendengaran}

Orang dapat mendengar sesuatu dengan alat pendengaran, yaitu telinga. Telinga merupakan salah satu alat untuk dapat mengetahui sesuatu yang ada di sekitarnya. Telinga dapat dibagi atas beberapa bagian yaitu telinga bagian luar merupakan bagian yang menerima stimulus dari luar kemudian 
telinga bagian tengah merupakan bagian yang meneruskan stimulus yang diterima bagian luar, jadi bagian ini merupakan transformer lalu telinga bagian dalam merupakan reseptor yang sensitif yang merupakan saraf-saraf penerima. (Walgito Bimo, 2004)

Mengenai pendengaran ini sedikit banyak sangat memberikan pengaruh terhadap penerapan teori persepsi karena pada dasarnya sesuatu tidak mesti dilihat tetapi hanya mendengar saja seseorang sudah bisa membuat suatu persepsi tertentu dan juga terhadap objek tertentu pula.

Syaraf pendengaran merupakan kemampuan untuk memberikan suatu pengamatan terhadap suara yang diterima melalui getaran udara. Begitupun pada saat seorang atau setiap individu mendengarkan suatu hal dari suatu objek tertentu, maka timbullah penerapan persepsi tersebut dari apa yang telah didengarnya. Mengenai pendengaran ini, sedikit banyak sangat memberikan pengaruh terhadap penerapan teori persepsi karena pada dasarnya sesuatu tidak mesti dilihat, tetapi hanya mendengar saja seseorang sudah bisa membuat suatu persepsi tertentu dan juga terhadap objek tertentu pula.

Dalam Iklan Lifebuoy 5 langkah lawan penyebaran virus corona (Covid19) juga menggunakan audio yang menarik karena iklan yang ditayangkan menggunakan lagu sehingga membuat masyarakat semakin tertarik dengan iklan ini. Seperti yang diungkapkan Ebit selaku masyarakat Kelurahan Tempel Rejo :

"Menurut saya artikulasi dan bahasa yang digunakan sangat jelas sehingga pesan yang ingin disampaikan terekam ke otak saya apalagi disampaikan dengan menggunakan nada dan menjadi sebuah lagu jadi mudah dihafal dan diingat"(Ebit, Wawancara, 2020)

Sesuai teori diatas peneliti ingin melihat bagaimana respon anak-anak setelah menonton iklan Lifebuoy pencegah virus corona. Peneliti juga telah melakukan wawancara kepada Mirna selaku ibu dari Satria warga kelurahan Tempel Rejo :

"Anak saya menjadi ikut bernyanyi ketika mendengarkan iklan Lifebuoy di televisi ia suka karena tidak. hanya ada gambar tetapi disertakan musik yang membuat anak saya mudah mengingatnya apalagi yang ditampilkan iklan Lifebuoy ada suara anak menggunakan seragam sekolah dasar. Iklan ini sangat membantu saya dan anak bagaimana tahapan menjaga kesehatan ditengah covid saat ini mengingat sekolah diliburkan jadi tidak ada edukasi langsung dari sekolah tentang pencegahan virus corona."(Mirna, Wawancara, 2020) 
Dari hasil wawancara dapat dianalisis bahwa teori penerapan melalui pendengaran sejalan dengan hasil dilapangan bahwa teori ini mengatakan proses terjadinya persepsi sangat berpengaruh dengan indra pendengaran sebab objek yang didengar menyampaikan informasi menggunakan suara sehingga khalayak mudah memahami isi pesan yang disampaikan.Iklan Lifebuoy 5 langkah lawan penyebaran virus corona (covid-19)mengisi suara dengan vokal yang jelas sehingga khalayak juga dapat mengingat tahapan pencegahan penyebaran virus covid-19. Iklan yang ditampilkan memang harus mempunyai kriteria yang menarik, dengan ini menjadikan citra iklan Lifebuoy menjadi lebih baik dan semakin diminati masyarakat khususnya Kelurahan Tempel Rejo.

Dari penerapan persepsi di atas bahwa proses terjadinya persepsi itu ada dua yaitu melalui penglihatan dan pendengaran, bahwa Iklan Lifebuoy 5 langkah lawan penyebaran virus corona (Covid-19) ini memang memberikan dampak yang positif bagi masyarakat Kelurahan Tempel Rejo. Sajian iklan berupa visual yang ditampilkan oleh iklan tersebut didesain sebaik mungkin. Iklan Lifebuoy menampilkan langkah-langkah cara melawan penyebaran virus corona dengan langsung dipraktekkan oleh talent, dan ditambah dengan keterangan yang ditulis semenarik mungkin. Dalam iklan tersebut berisikan praktek mencuci tangan menggunakan sabun serta mengaplikasikan hand sanitizer, jika sakit segera ke dokter dan tidak berkumpul di tempat keramaian. Oleh sebab itu melalui iklan berupa visual yang menarik ini sangat membantu masyarakat untuk mengikuti langkah-langkah mencegah penyebaran virus corona (covid-19), sehingga masyarakat Tempel Rejo dapat dengan mudah untuk mempraktekkannya di kehidupan sehari-hari.

Kemudian sajian berupa audio yang dikemas oleh iklan Lifebuoy juga berhasil menarik perhatian masyarakat karena menggunakan musik dan bahasa yang mudah dimengerti sehingga dapat dengan mudah untuk dihafal terkait apa saja tahapan-tahapan untuk lawan penyebaran virus corona, hal ini tentunya dapat terekam di dalam memori khalayak karena bahasa dan artikulasi yang jelas.

Penerapan persepsi penglihatan dan pendengaran memang sangat efektif dalam menentukan persepsi seseorang karena khalayak dapat melihat dan mendengar langsung informasi yang disampaikan sehingga menumbuhkan persepsi terhadap objek yang dilihat. Iklan Lifebuoy 5 langkah lawan penyebaran virus corona (covid-19) bisa dikatakan berhasil dalam menumbuhkan persepsi yang positif bagi khalayak, terbukti dengan sajian iklan yang disampaikan 
dengan perpaduan audio visual yang didesain semenarik mungkin, membuat masyarakat tertarik untuk melihat dan mengikutinya.

\section{PENUTUP}

Masyarakat melihat Iklan Lifebuoy 5 langkah lawan penyebaran virus corona (covid-19) ini sangat bagus dan memberikan persepsi yang positif karena tampilan audio visual yang disajikan mudah dipahami oleh masyarakat. Upaya Iklan Lifebuoy 5 langkah lawan penyebaran virus corona (covid-19) ini sangat berhasil memberikan efek yang positif bagi masyarakat. Lewat sajian audio visual yang didesain menarik, masyarakat tidak kesulitan untuk meniru dan mempraktekkan dalam kehidupan sehari-hari.Hal ini tentu sangat membantu pemerintah dalam upaya memberikan edukasi ke masyarakat terkait cara melawan penyebaran virus corona. Sehingga masyarakat lebih mudah memahami bagaimana cara yang baik dan benar untuk mencegah penyebaran virus corona. Hal ini juga menjadi salah satu penyebab masyarakat Tempel Rejo bisa terlindungi dari penyebaran virus corona (Covid-19).

\section{DAFTAR REFERENSI}

Adityo Susilo, dkk. (2020). Coronavirus Disease 2019: Review of Current Literatures, Jurnal Penyakit Dalam Indonesia . 7(1)

Ambar Lukitaningsih. (2013) Iklan Yang Efektif Sebagai Strategi Komunikasi Pemasaran, Jumal Ekonomi dan Kewirausahaan. 13 (2)

Babbie E. 1992. The Practice of Social Research. Sixth Edition. Wadsworth Publishing Company. California

Dedy Mulyana dan Solatun, (2007).Metode Penelitian Komunikasi, Bandung: PT Remaja Rosdakarya

Handari Nawawi, (1990) Metodologi Penelitian Bidang Sosial, (Yogyakarta : Gajah Mada University Press

Hasna Nur Lina, Lidwina Mutia S, (2021). Audiens Milenial dan Iklan Viral: Kajian Daya Tarik Iklan \#KerenLahirBatin terhadap Brand Image Ramayana Department Store, Jurnal Media dan Komunikasi Indonesia. 1(1)

bttp://digilib.unila.ac.id/8016/14/BAB\%20II.pdfdiakses pada tanggal01 Oktober 2020

https://m.cnnindonesia.com/nasional/20201001093050-20-553035 diakses pada tanggal 01 Oktober 2020 
https://www.klikdokter.com/info-sehat/read/3640071/cuci-tangan-carapaling-ampuh-dan-mudah-perangi-covid-19 diakses pada tanggal 04 Oktober 2020

https:// www.merdeka.com/trending/kronologi-munculnya-covid-19-di-indonesia-binggaterbit-keppres-darurat-kesehatan-kln.btmldiakses pada 01 Oktober 2020

Koenjradiningrat, (1997) Metode-Metode Penelitian Masyarakat, Jakarta : Gramedia,

Lexy J. Moleong, (2006). Metodologi Penelitian Kualitatif, Edisi Revisi Bandung : PT. Rosda Karya,

Morissan (2008). Manajemen Media Penyiaran, Jakarta: Prenadamedia Group

Noeng Muhadjir, (1998)Metodologi Penelitian Kualitatif, Yogyakarta : Rake Serasin.

Nuzuli, A. K. (2018). Audiences Meanings on Figure Disabilities in Korean Drama Scarlet Heart. Proceedings of the International Conference on Media and Communication Studies 2018). https://doi.org/10.2991/icomacs-18.2018.30

Nuzuli, A. K. (2020a). Komunikasi Orang Tua dalam Mengurangi Stres Mahasiswa Perantauan Pasca Larangan Mudik Covid 19. In Diskursus Covid 19 dalam Prespektif Komunikasi. Aspikom.

Nuzuli, A. K. (2020b). Komunikasi Orang Tua dan Tingkat Stres Mahasiswa Perantauan Pada Larangan Mudik Covid 19. Komunida: Media Komunikasi Dan Dakwah, 10(3).

https://doi.org/https://doi.org/10.35905/komunida.v10i02.1525

Priliantini, A. (2017). Menilik Dilema Ideologi Radio Swasta Lokal Dan Strategi Periklanannya. Jumal Komunikasi, Media Dan Informatika, 6(2),

Ronald B. Adler \& George Rodman, (2006) Understanding Human Communication, New York: Oxford University Press,.

Shafa Tsamara Nugraini, Abdul Kholik, (2021), Covid-19 Data Management Strategy By Diskominfo Bogor City, Jurnal Media dan Komunikasi Indonesia, Vol 2, No 2

Sugiyono, (2014),Memahami Penelitian Kualitatif, Bandung: ALFABETA

Suharsimi Arikunto, (2006).Prosedur Penelitian, Jakarta:Rineka Cipta,

Sukarman Syarnubi, (2008) Metodologi Penelitian Kuantitatif dan Kualitatif, Lembaga Penerbit dan Percetakan (Lp2)Stain Curup

Tan, Alexis. 1981. Mass Communication Theories and Research. Columbus -Ohio: Grid publishing Inc. 
Edo Wiranto, Robby Aditya Putra dan Hariya Toni, Persepsi iklan Lifebuoy Pencegah Covid-19 di Kelurahan Tempel Rejo Rejang Lebong

W. Syam Nina, (2011), Psikologi Akar Ilmu Komunikasi, Bandung:Simbiosa Rekatama Media

Walgito Bimo, (2004), Pengantar Psikologi Umum, Yogyakarta:CV ANDI OFFSET, 